\title{
Flow rate and inorganic components of submandibular saliva in cystic fibrosis
}

\author{
JEANETTE BLOMFIELD, KATHRYN L. WARTON, and J. M. BROWN \\ From the Children's Medical Research Foundation and Cystic Fibrosis Clinic, \\ Royal Alexandra Hospital for Children, Sydney, Australia
}

\begin{abstract}
Blomfield, J., Warton, K. L., and Brown, J. M. (1973). Archives of Disease in Childhood, 48, 267. Flow rate and inorganic components of submandibular saliva in cystic fibrosis. The inorganic components of submandibular saliva were determined in 35 patients with cystic fibrosis and in 28 controls. No differences due to flow rate were apparent between the two groups. At comparable flow rates, cystic fibrosis submandibular saliva had higher concentrations of calcium, sodium, and chloride, and similar concentrations of magnesium, inorganic phosphate, potassium, copper, and zinc. The insoluble, turbid fraction of the cystic fibrosis submandibular saliva contained both calcium and phosphate, and these were precipitated in a ratio which was consistent with hydroxyapatite. The secretory granules are postulated as the source of the excess calcium in cystic fibrosis submandibular saliva.
\end{abstract}

The calcium concentration of the turbid submandibular saliva of cystic fibrosis (CF) subjects has consistently been found to be raised (Chernick, Barbero, and Parkins, 1961; Mandel et al., 1967, 1969; Wiesmann et al., 1968; Zipkin et al., 1970), but controversy still surrounds the flow ratedependent sodium, chloride, and phosphate ions (Chernick et al., 1961; Mandel et al., 1967; Wiesmann et al., 1968; Wiesmann, Boat and di Sant' Agnese, 1970; Zipkin et al., 1970), and values for the divalent cations magnesium, copper, and zinc have not been recorded. Though calcium is known to be present in the turbid fraction of the saliva (Gugler et al., 1967), the association of inorganic phosphate with this insoluble calcium had not been previously determined. A preliminary report derived from this present study of the relation of calcium to phosphate in the centrifuged deposit and its identification as hydroxyapatite by $x$-ray powder diffraction studies has been published (Warton and Blomfield, 1971).

This report details the influence of flow rate on inorganic ion secretion in submandibular saliva, and the differences and similarities found between $\mathrm{CF}$ and control subjects.

\section{Subjects and methods}

Subjects. Of 35 ambulatory CF patients, 19 were male aged 4 to 18 years, and 16 were female aged 5

Received 7 August 1972. to 21 years. The control group comprised 28 healthy subjects of whom 20 were male aged 5 to 18 years, and 8 were female aged 8 to 12 years.

Collection of saliva. The method of collection was based on the procedure of Mandel et al. (1969). Cotton wool rolls were positioned opposite the openings of the parotid ducts. Salivary flow was stimulated by placing two drops of $10 \%$ citric acid on a $1 \cdot 25 \mathrm{~cm}$ filter paper disc on the tongue for 30 seconds. The saliva pooling under the tongue was collected for the next 30 seconds using a soft polyvinyl infant nasal feeding tube attached to a polypropylene syringe, and this initial sample was discarded. The subsequent 3minute sample was collected similarly, and transferred to a graduated centrifuge tube. Flow rate was calculated from the volume and collection time ( 3 minutes).

Collections were performed at least 1 hour after oral intake. Saliva collected at the first visit was not included in the study, and, wherever possible, four samples were subsequently collected from each subject.

Preparation of saliva. Samples were centrifuged with a minimum time lag after collection in a Sorvall RC2-B superspeed centrifuge at $37,000 \mathrm{~g}$ and $2^{\circ} \mathrm{C}$ for 30 minutes, yielding a deposit and a clear supernatant. The deposit was dissolved in $4 \mathrm{~N} \mathrm{HCl}$ to the original sample volume. Analyses were performed on both supernatant and dissolved deposit, and results were expressed as total (supernatant plus deposit) or as deposit values.

Analytical procedures. Calcium, magnesium, sodium, potassium, copper, and zinc were all analysed 
by atomic absorption spectrophotometry, using a Perkin-Elmer model 303. For calcium and magnesium, the samples were diluted 1 in 20 in lanthanum chloride containing La 5000 p.p.m. (Gow, 1965a, b). For sodium, the samples were diluted 1 in 400 with a solution containing 100 p.p.m. potassium (Dawes, 1969), and for potassium a 1 in 400 dilution was made with a solution containing 100 p.p.m. sodium (Dawes, 1969). For copper and zinc, the supernatant aliquot was diluted with 1 volume of $4 \mathrm{~N} \mathrm{HCl}$, followed by 2 volumes of acetone to precipitate the protein and increase sensitivity.

Phosphate was measured by the ascorbic acid molybdate method of Chen, Toribara, and Warner (1956), using a Shimadzu AQ50 spectrophotometer.

Chloride was also determined spectrophotometrically by a modification of the method of Zall, Fisher, and Garner (1956). Supernatant diluted 1 in 20 in deionized water was mixed with an equal volume of the reagent mixture containing mercuric thiocyanate, ferric nitrate, and mercuric nitrate, and the resultant colour was measured spectrophotometrically.

\section{Calcium.}

\section{Results}

Total. In the CF patients the mean total calcium concentration was raised $(P<0.001)$ at all flow rates (Table I, Fig. 1). There was, however, considerable overlap between the lowest CF values and the highest control values. There did not appear to be any effect due to flow rate.

Deposit. In the centrifuged deposit, the mean values of insoluble calcium for the $\mathrm{CF}$ patients was greater $(P<0.001)$ than for the controls at all flow rates (Table II, Fig. 1). There was appreciable overlap between the two groups of subjects.

\section{Magnesium.}

Total. The magnesium content of the submandibular saliva was not significantly different in CF patients and controls (Table I, Fig. 2). Magnesium concentration tended to be higher at the lowest flow rates.

Deposit. The deposit magnesium tended to diminish with flow rate (Fig. 2). Statistically there was significantly $(P<0.001)$ more insoluble magnesium in the CF saliva in the intermediate flow rates, but not at the lowest or highest flow rates (Table II).

\section{Inorganic phosphate.}

Total. There was little difference in the total inorganic phosphate, except that the control levels were more influenced by flow rate, the mean being greater than the CF mean at the lowest flow rates, and less at the highest flow rates (Table I, Fig. 3).

Deposit. Except at the lowest flow rates where the insoluble inorganic phosphate was a little greater $(P<0.05)$ in the controls than in the patients, the deposit phosphate was greater $(P<0.001)$ in the CF patients (Table II, Fig. 3).

TABLE I

Total concentration of inorganic components and flow rate

\begin{tabular}{|c|c|c|c|c|c|c|c|c|c|}
\hline \multirow{3}{*}{$\begin{array}{l}\text { Inorganic } \\
\text { components }\end{array}$} & \multicolumn{9}{|c|}{ Flow rate $(\mathrm{ml} / \mathrm{min})$} \\
\hline & \multicolumn{3}{|c|}{$<0 \cdot 25$} & \multicolumn{3}{|c|}{$0 \cdot 25-0 \cdot 50$} & \multicolumn{3}{|c|}{$>0.50$} \\
\hline & $\begin{array}{l}\text { Cystic } \\
\text { fibrosis }\end{array}$ & Controls & $\mathbf{P}$ & $\begin{array}{l}\text { Cystic } \\
\text { fibrosis }\end{array}$ & Controls & $\mathbf{P}$ & $\begin{array}{l}\text { Cystic } \\
\text { fibrosis }\end{array}$ & Controls & $\mathbf{P}$ \\
\hline Calcium & $\begin{array}{c}4 \cdot 5 \pm 1 \cdot 0 \\
(66)\end{array}$ & $\begin{array}{c}3 \cdot 0 \pm 0 \cdot 6 \\
(42)\end{array}$ & & $\begin{array}{c}4 \cdot 7 \pm 1 \cdot 2 \\
(48)\end{array}$ & $\begin{array}{c}2 \cdot 9 \pm 0 \cdot 6 \\
(42)\end{array}$ & $<0.001$ & $\begin{array}{c}4 \cdot 8 \pm 0 \cdot 7 \\
(9)\end{array}$ & $\begin{array}{c}2 \cdot 8 \pm 0 \cdot 6 \\
(25)\end{array}$ & $<0.001$ \\
\hline Magnesium & $\begin{array}{c}0.19 \pm 0.06 \\
(66)\end{array}$ & $\begin{array}{c}0 \cdot 20 \pm 0.07 \\
(41)\end{array}$ & NS & $\begin{array}{c}0.14 \pm 0.05 \\
(47)\end{array}$ & $\begin{array}{c}0 \cdot 12 \pm 0 \cdot 04 \\
(42)\end{array}$ & NS & $\begin{array}{c}0.12 \pm 0.03 \\
(6)\end{array}$ & $\begin{array}{c}0.13 \pm 0.04 \\
(25)\end{array}$ & NS \\
\hline $\begin{array}{l}\text { Inorganic } \\
\text { phosphate }\end{array}$ & $\begin{array}{c}7 \cdot 3 \pm 1 \cdot 5 \\
(59)\end{array}$ & $\begin{array}{c}8 \cdot 5 \pm 1 \cdot 8 \\
(41)\end{array}$ & NS & $\begin{array}{c}6 \cdot 6 \pm 1 \cdot 3 \\
(48)\end{array}$ & $\begin{array}{c}6 \cdot 5 \pm 1 \cdot 4 \\
(42)\end{array}$ & NS & $\begin{array}{c}6 \cdot 5 \pm 0 \cdot 7 \\
(9)\end{array}$ & $\begin{array}{c}5 \cdot 6 \pm 0 \cdot 7 \\
(25)\end{array}$ & $<0.01$ \\
\hline Sodium & $\begin{array}{c}5 \cdot 4 \pm 4 \cdot 8 \\
(57)\end{array}$ & $\begin{array}{c}1 \cdot 5 \pm 2 \cdot 7 \\
(39)\end{array}$ & $<0.001$ & $\begin{array}{c}9 \cdot 7 \pm 5 \cdot 8 \\
(44)\end{array}$ & $\begin{array}{c}3 \cdot 1 \pm 5 \cdot 8 \\
(42)\end{array}$ & $<0.001$ & $\begin{array}{c}18 \cdot 4 \pm 6 \cdot 1 \\
(9)\end{array}$ & $\begin{array}{c}7 \cdot 5 \pm 4 \cdot 2 \\
(25)\end{array}$ & $<0.001$ \\
\hline Potassium & $\begin{array}{c}16 \cdot 3 \pm 2 \cdot 7 \\
(45)\end{array}$ & $\begin{array}{c}16 \cdot 2 \pm 3 \cdot 7 \\
(22)\end{array}$ & NS & $\begin{array}{c}15 \cdot 5 \pm 3 \cdot 8 \\
(44)\end{array}$ & $\begin{array}{c}15 \cdot 4 \pm 2 \cdot 9 \\
(42)\end{array}$ & NS & $\begin{array}{c}17 \cdot 0 \pm 5 \cdot 7 \\
(9)\end{array}$ & $\begin{array}{l}15 \cdot 1 \pm 2 \cdot 2 \\
(25)\end{array}$ & NS \\
\hline Chloride & $\begin{array}{c}16 \cdot 3 \pm 4 \cdot 6 \\
(30)\end{array}$ & $\begin{array}{c}11 \cdot 6 \pm 3 \cdot 5 \\
(13)\end{array}$ & $<0.001$ & $\begin{array}{c}16 \cdot 7 \pm 5 \cdot 2 \\
(47)\end{array}$ & $\begin{array}{c}10 \cdot 4 \pm 4 \cdot 3 \\
(42)\end{array}$ & $<0.001$ & $\begin{array}{c}24 \cdot 9 \pm 5 \cdot 4 \\
(9)\end{array}$ & $\begin{array}{c}10 \cdot 8 \pm 4 \cdot 1 \\
(25)\end{array}$ & $<0.001$ \\
\hline Copper & - & - & 一 & $\begin{array}{c}17 \cdot 8 \pm 8 \cdot 4 \\
(33)\end{array}$ & $\begin{array}{c}17 \cdot 4 \pm 9 \cdot 4 \\
(36)\end{array}$ & NS & $\begin{array}{c}22 \cdot 6 \pm 9 \cdot 9 \\
(9)\end{array}$ & $\begin{array}{c}20 \cdot 0 \pm 9 \cdot 5 \\
(25)\end{array}$ & NS \\
\hline Zinc & - & - & 一 & $\begin{array}{c}18 \cdot 5 \pm 7 \cdot 7 \\
(36)\end{array}$ & $\begin{array}{c}15 \cdot 6 \pm 9 \cdot 9 \\
(36)\end{array}$ & NS & $\begin{array}{c}19 \cdot 6 \pm 7 \cdot 0 \\
(9)\end{array}$ & $\begin{array}{c}13 \cdot 6 \pm 7 \cdot 0 \\
(25)\end{array}$ & $<0.05$ \\
\hline
\end{tabular}

Note: $\mathrm{Ca}^{++}, \mathrm{Mg}^{++}, \mathrm{HPO}_{4}^{--}, \mathrm{Na}^{+}, \mathrm{K}^{+}$, and $\mathrm{Cl}^{-}$are expressed as $\mathrm{mEq} / \mathrm{l}$; $\mathrm{Cu}^{++}$and $\mathrm{Zn}^{++}$are expressed as $\mu \mathrm{g} / 100 \mathrm{ml}$. Results are given as mean $\pm S D$. In parentheses are the number of samples analysed. 

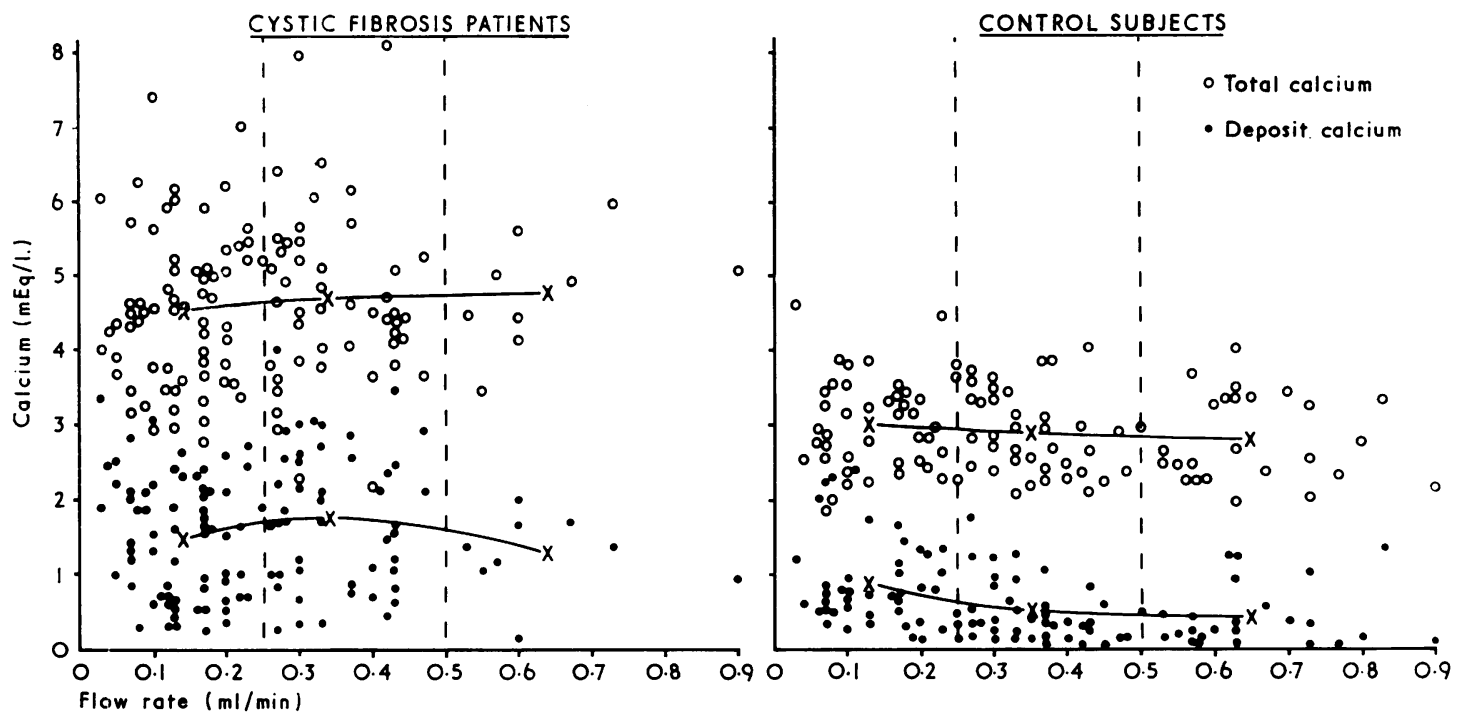

Fig. 1.-Relation of calcium concentration to flow rate in submandibular saliva. Flow rates were divided into 3 groups: $<0.25 \mathrm{ml} / \mathrm{min}, 0.25$ to $0.50 \mathrm{ml} / \mathrm{min}$, and $>0.50 \mathrm{ml} / \mathrm{min}$. Mean concentration of calcium in each of these groups is plotted against mean flow rate of the group.

TABLE II

Deposit concentration of inorganic components and flow rate

\begin{tabular}{|c|c|c|c|c|c|c|c|c|c|}
\hline \multirow{3}{*}{$\begin{array}{l}\text { Inorganic } \\
\text { components }\end{array}$} & \multicolumn{9}{|c|}{ Flow rate $(\mathrm{ml} / \mathrm{min})$} \\
\hline & \multicolumn{3}{|c|}{$<0 \cdot 25$} & \multicolumn{3}{|c|}{$0 \cdot 25-0.50$} & \multicolumn{3}{|c|}{$>0.50$} \\
\hline & $\begin{array}{l}\text { Cystic } \\
\text { fibrosis }\end{array}$ & Controls & $\mathbf{P}$ & $\begin{array}{l}\text { Cystic } \\
\text { fibrosis }\end{array}$ & Controls & $\mathbf{P}$ & $\begin{array}{l}\text { Cystic } \\
\text { fibrosis }\end{array}$ & Controls & $\mathbf{P}$ \\
\hline Calcium & $\begin{array}{c}1 \cdot 5 \pm 0 \cdot 8 \\
(66)\end{array}$ & $\begin{array}{c}0.9 \pm 0.6 \\
(42)\end{array}$ & $<0.001$ & $\begin{array}{c}1 \cdot 8 \pm 0.9 \\
(48)\end{array}$ & $\begin{array}{c}0.5 \pm 0 \cdot 4 \\
(42)\end{array}$ & $<0.001$ & $\begin{array}{c}1 \cdot 3 \pm 0.5 \\
(9)\end{array}$ & $\begin{array}{c}0.4 \pm 0.4 \\
(25)\end{array}$ & $<0.001$ \\
\hline Magnesium & $\begin{array}{c}0.04 \pm 0.02 \\
(66)\end{array}$ & $\begin{array}{c}0.04 \pm 0.02 \\
(41)\end{array}$ & NS & $\begin{array}{c}0.03 \pm 0.01 \\
(47)\end{array}$ & $\begin{array}{c}0.02 \pm 0.01 \\
(42)\end{array}$ & & $\begin{array}{c}0.02 \pm 0.01 \\
(6)\end{array}$ & $\begin{array}{c}0.02 \pm 0.01 \\
(25)\end{array}$ & NS \\
\hline $\begin{array}{l}\text { Inorganic } \\
\text { phosphate }\end{array}$ & $\begin{array}{c}1 \cdot 0 \pm 0 \cdot 6 \\
(59)\end{array}$ & $\begin{array}{c}1 \cdot 3 \pm 0 \cdot 7 \\
(41)\end{array}$ & $<0.05$ & $\begin{array}{c}1 \cdot 2 \pm 0 \cdot 7 \\
(48)\end{array}$ & $\begin{array}{c}0.3 \pm 0.3 \\
(42)\end{array}$ & $<0.001$ & $\begin{array}{c}0.8 \pm 0 \cdot 2 \\
(9)\end{array}$ & $\begin{array}{c}0.3 \pm 0.3 \\
(25)\end{array}$ & $<0.001$ \\
\hline
\end{tabular}

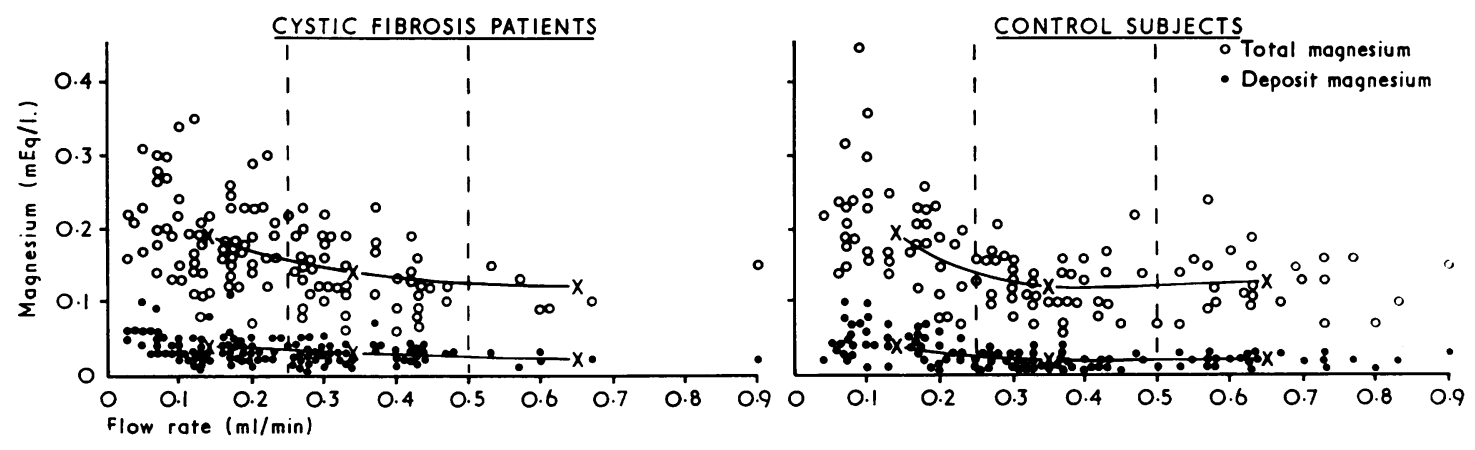

FIG. 2.-Relation of magnesium concentration to flow rate in submandibular saliva. 

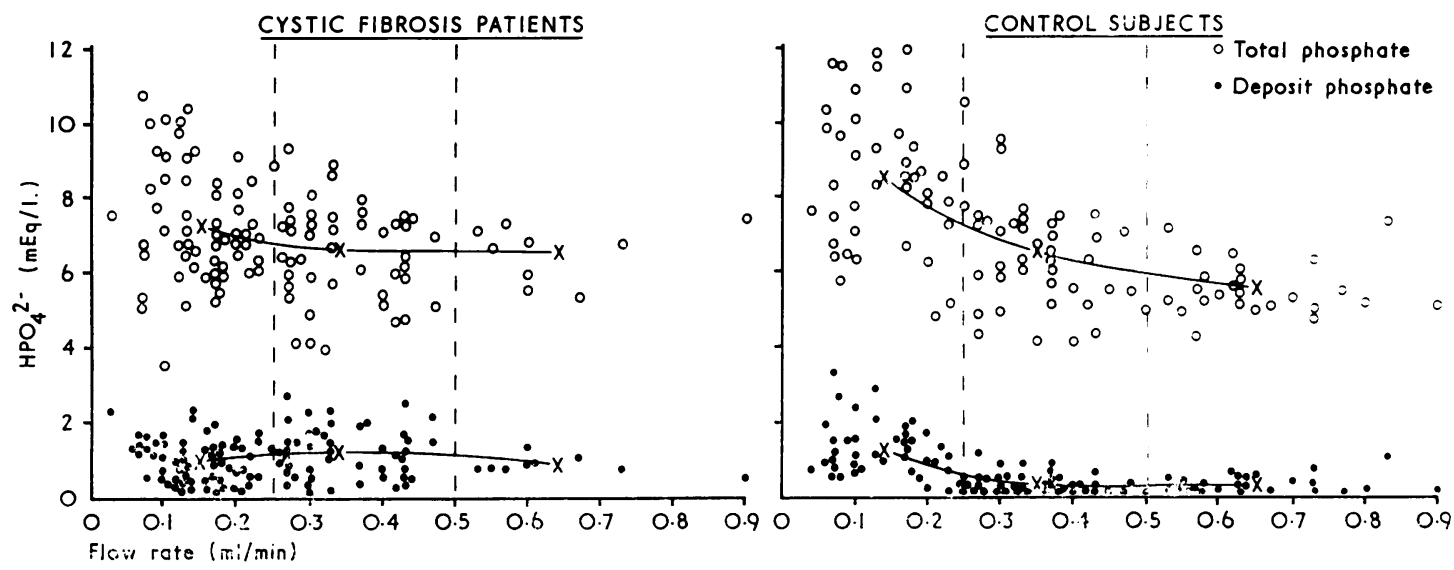

FIG. 3.-Relation of inorganic phosphate to flow rate in submandibular saliva.

The insoluble phosphate diminished with flow rate in the controls but not in the CF patients.

Sodium. Sodium was increased $(P<0.001)$ in the CF subjects at all flow rates (Table I, Fig. 4). In both groups the sodium concentration increased with increasing flow rates.

Potassium. Potassium was not significantly different in the two groups (Table I, Fig. 5), and was not affected by flow rate.

Chloride. In the CF patients, chloride was raised $(P<0 \cdot 001)$ at all flow rates (Table I, Fig. 6).
Copper. Copper concentrations were not significantly different in patients and controls (Table I, Fig. 7).

Zinc. Zinc was not significantly increased in the CF patients except at the highest flow rates $(P<0.05)$ (Table I, Fig. 8).

Deposit calcium : phosphorus ratio. In the deposit of the CF submandibular saliva, calcium and phosphate were precipitated in a fixed ratio with a mean molar $\mathrm{Ca} / \mathrm{P}$ ratio of 1.5 for all flow rates (Fig. 9). Consistent mean $\mathrm{Ca} / \mathrm{P}$ ratios of $1 \cdot 54$, 1.51 , and 1.49 were found at flow rates of $<0.25$,
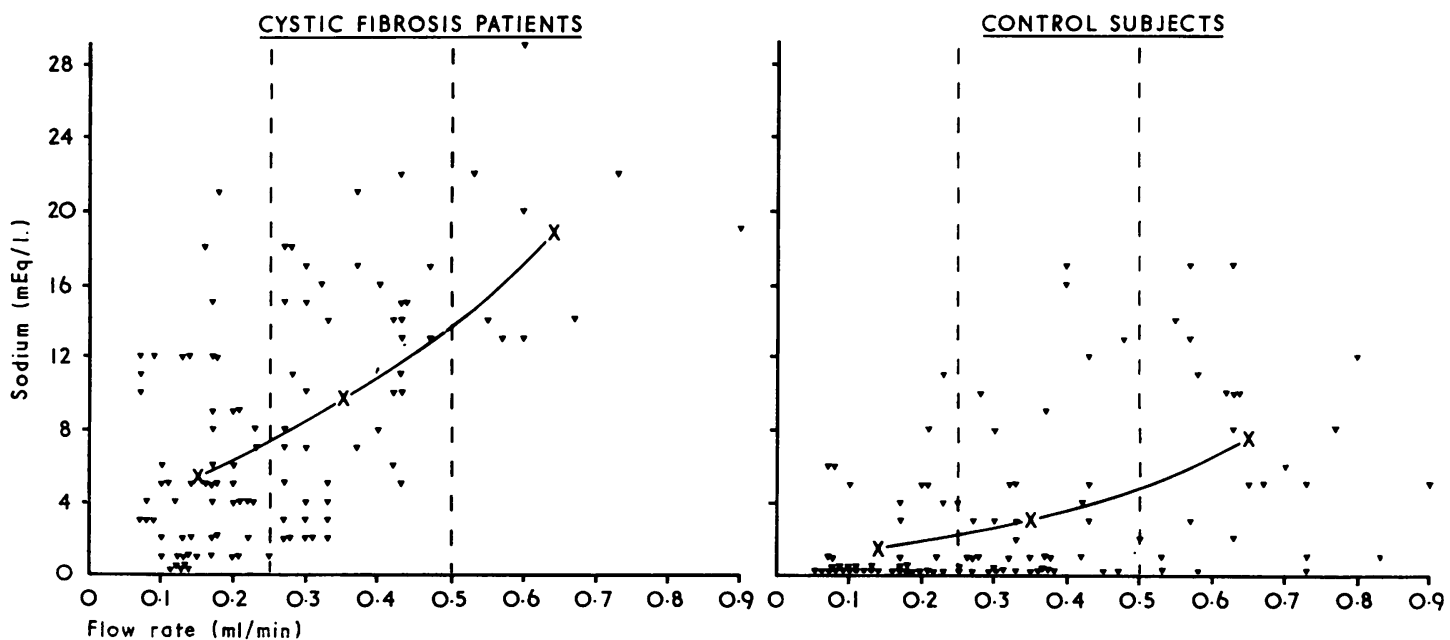

FiG. 4.-Relation of sodium to flow rate in submandibular saliva. 
Flow rate and inorganic components of submandibular saliva in cystic fibrosis

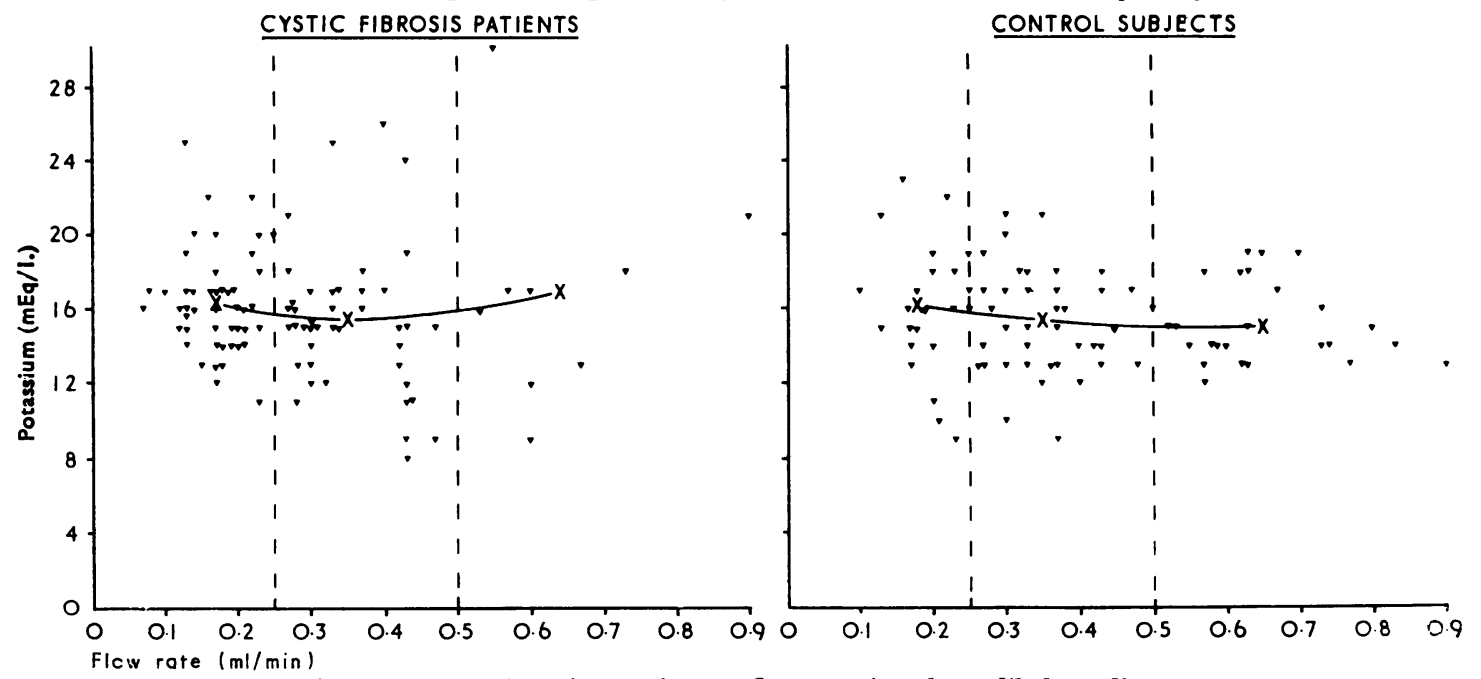

Fig. 5.-Relation of potassium to flow rate in submandibular saliva.

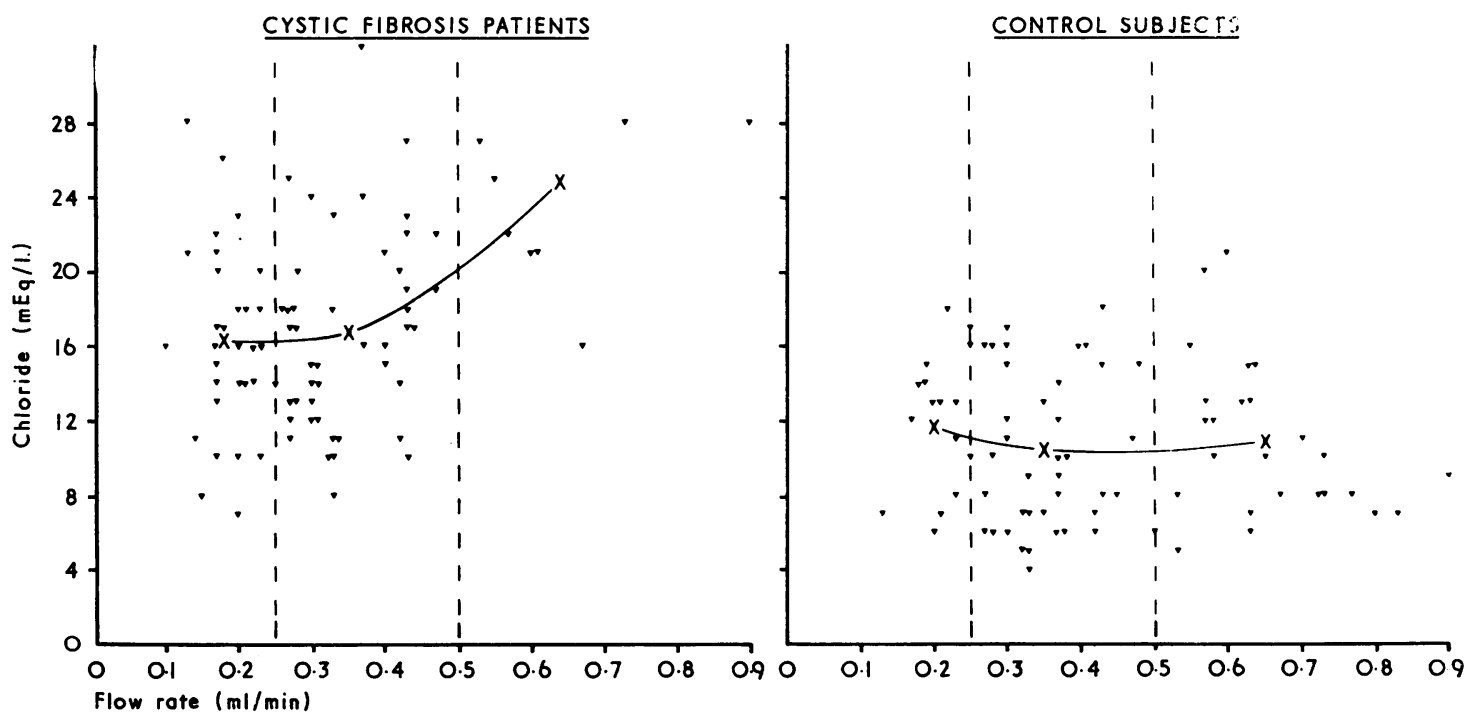

FIG. 6.-Relation of chloride to flow rate in submandibular saliva.

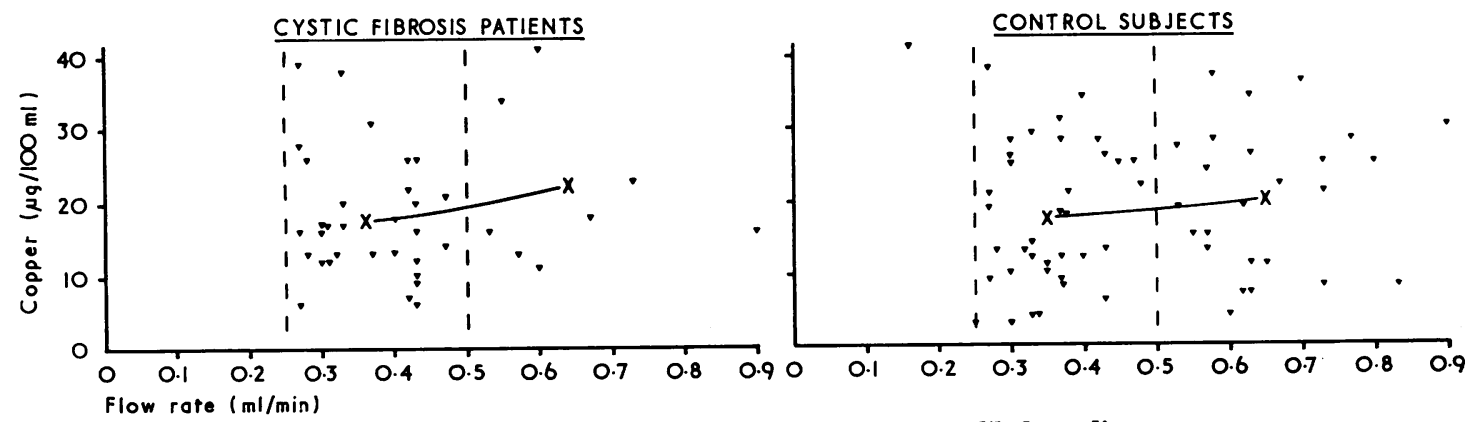

FIG. 7.-Relation of copper to flow rate in submandibular saliva. 

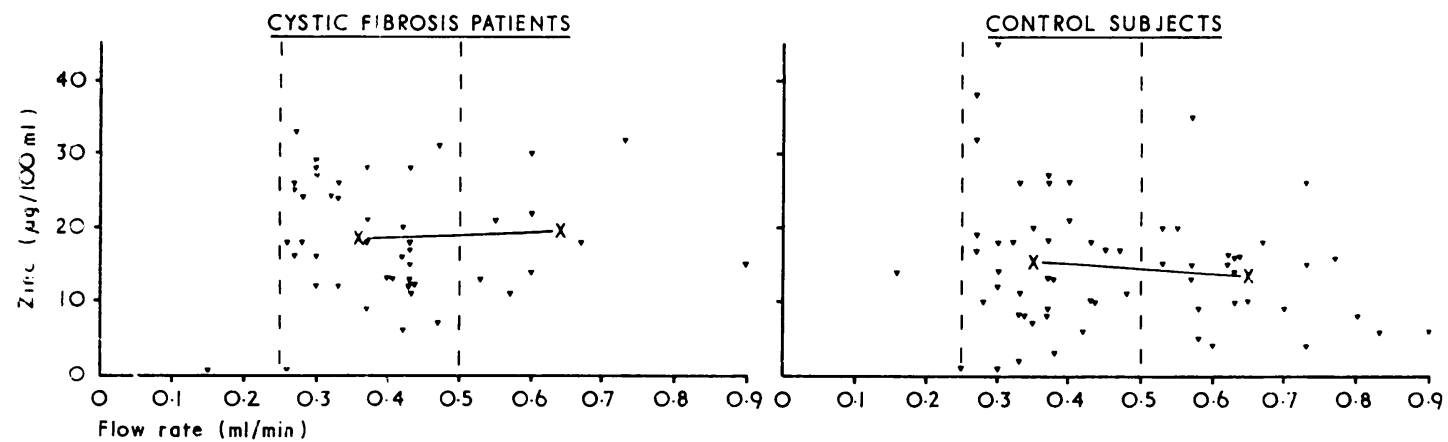

Fig. 8.- Relation of zinc to flow rate in submandibular saliva.
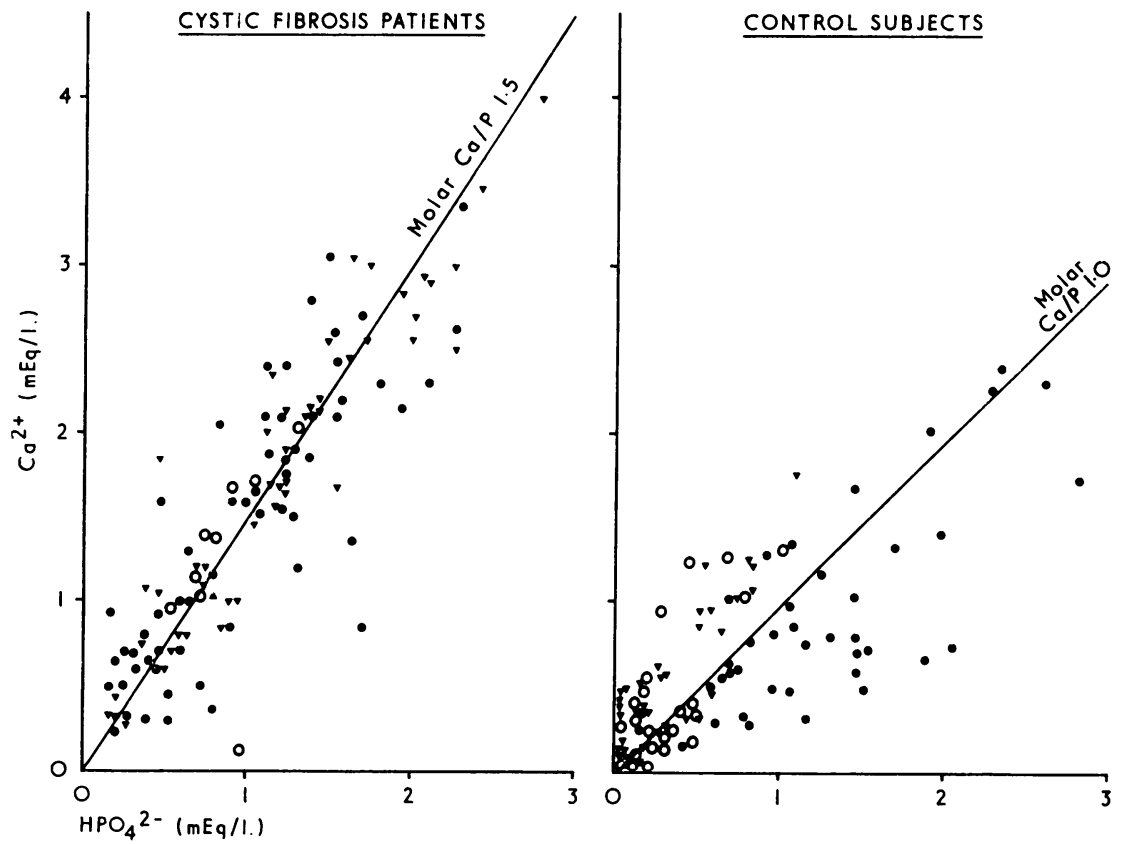

FIG. 9.-Relation of calcium : phosphate in the insoluble deposit of submandibular saliva. ๑, values at flow rates of $<0.25 \mathrm{ml} / \mathrm{min} ; \nabla$, values at flow rates of 0.25 to $0.50 \mathrm{ml} / \mathrm{min}$; $O$, values at flow rates of $>0.50 \mathrm{ml} / \mathrm{min}$.

0.25 to 0.50 , and $>0.50 \mathrm{ml} / \mathrm{min}$, respectively, in the CF patients. For the controls, the mean molar $\mathrm{Ca} / \mathrm{P}$ ratios for the 3 flow rates were $0 \cdot 72,1 \cdot 75$, and $1.45 \mathrm{ml} / \mathrm{min}$, with an overall mean of $1 \cdot 0$.

Flow rate. The overall flow rate of the $C F$ patients was lower $(P<0.001)$ than the controls. The mean flow rate of the CF patients was $0 \cdot 26 \pm$ $0.15 \mathrm{ml} / \mathrm{min}$, and of the controls $0.34 \pm 0.20$ $\mathrm{ml} / \mathrm{min}$.

\section{Discussion}

Although the mean flow rate of the CF patients was lower than in the controls, the influence of flow rate on secretion of inorganic constituents was similar in the two groups. Thus calcium, potassium, copper, and zinc were unaffected by flow rate, magnesium and inorganic phosphate were highest at the slowest flow rates, and sodium increased as the rate of secretion increased. Chloride appeared to increase in the CF patients at high flow rates.

In terms of concentration the CF patients had more calcium, sodium, and chloride in the submandibular saliva than the controls, but the 
amounts of magnesium, inorganic phosphate, potassium, copper, and zinc were similar at comparable flow rates.

Comparison with previous studies is difficult because of differing methods of collection and stimulation. In all studies, the mean calcium level has been found to be increased (Chernick et al., 1961; Mandel et al., 1967, 1969; Wiesmann et al., 1968; Zipkin et al., 1970). Phosphate has been reported to be higher in CF patients (Mandel et al., 1967, 1969; Zipkin et al., 1970), but in one study where the effect of flow rate was taken into account, an increase was evident only at high flow rates (Wiesmann et al., 1968).

Although we cannot exclude the possibility that, with our collection method, minor salivary glands (Wiesmann et al., 1970) may have contributed to the increased sodium content of CF saliva, our results are comparable with those of Mandel et al. (1967) who used Block and Brotman collectors. Chernick et al. (1961), who used modified Schneyer collectors, considered the sodium values to be comparable in patients and controls, though with methacholine stimulation the mean sodium values for the CF group were higher than controls at comparable flow rates. With unstimulated submandibular saliva, CF patients and controls had comparable sodium levels at similar flow rates (Wiesmann et al., 1968)

The most interesting finding of this study has been that the turbid, insoluble fraction of the CF saliva contains not only a large proportion of the calcium, but that phosphate is precipitated with the calcium. The molar $\mathrm{Ca} / \mathrm{P}$ ratio in the centrifuged deposit is consistent with hydroxyapatite, and, as previously reported (Warton and Blomfield, 1971), the presence of hydroxyapatite in the ashed deposit has been confirmed by $x$-ray powder diffraction analysis. It has been postulated that, though the total phosphate is not raised in the CF submandibular saliva, the increased calcium concentrations have raised the $\mathrm{Ca} \times \mathrm{P}$ product beyond the solubility limit, with resultant precipitation.

In CF submandibular saliva the calcium concentration has a mean level approximately twice the plasma ionized calcium level, so that the raised calcium cannot have been derived solely from passive diffusion. Nor would a defective calcium pump (Horton, Cole, and Bader, 1970) explain the rise; but rather an overactive calcium pump would need to be postulated. An alternative postulate to increased transport of ionic calcium is that there is an additional method of calcium transfer in which calcium is extruded with protein, and that this pathway is overactive in the CF cells.
Dreisbach (1964) has shown in the rat submandibular gland that chronic administration of isoprenaline causes a marked increase in calcium storage in association with enlargement of the gland. The enlargement is due to hypertrophy and hyperplasia of the acini (Seifert, 1967). Further, Dreisbach has shown that acute administration of isoprenaline causes a rapid release of calcium into the saliva, accompanied by depletion of gland calcium. The depletion continues for 2 to 4 hours, then reaccumulation occurs. $\mathrm{He}$ has suggested that the greater depletion of calcium induced by isoprenaline compared to pilocarpine probably results from a greater loss of secretory granules after sympathomimetic than after parasympathomimetic drugs. He further postulated that the raised calcium in the saliva might be due to a calcium-binding substance preventing diffusion, and that such a substance could be liberated from secretory granules at the same time that calcium was lost from the gland.

Wallach and Schramm (1971) have found in the parotid gland of the rat that calcium was accumulated in the secretory granules, and that it was secreted concomitantly with the protein. A calcium pump was demonstrated in the smooth membrane vesicles (Selinger, Naim, and Lasser, 1970), which are abundant in the area of the Golgi complex, though as yet a positive connexion between these vesicles and the secretory granules has not been established. An increased production and release of secretory granules therefore appears to account for the accumulation and release of calcium induced by isoprenaline administration.

By autoradiography with ${ }^{45} \mathrm{Ca}$, Taugner and Dreisbach (1972) found preferential in vitro accumulation of calcium by the acinar cells of rat submandibular gland. With metabolic inhibition at $1{ }^{\circ} \mathrm{C}$, and with cyanide, calcium uptake by the acinar cells was abolished, but accumulation continued in the granular tubule cells. With acetylcholine and with isoprenaline the contrast in calcium storage between acinar cells and granular tubule cells disappeared. These results show two different cellular storage patterns for calcium in the different cells, though this does not necessarily indicate separate secretory pathways.

In CF, submandibular saliva calcium is raised. Evidence consistent with increased secretory granule release includes the higher levels of protein (Chernick et al., 1961; Mandel et al., 1967) and enzymes (Chernick, Eichel, and Barbero, 1964; Mandel et al., 1967), and electron microscope demonstration of abundant particles resembling the contents of secretory granules in CF sub- 
mandibular saliva (Blomfield, 1972). Secretion of calcium in extruded granule contents is therefore consistent with the evidence, though not yet proven. It is postulated that the additional pathway of calcium release in the submandibular gland is via the extruded contents of the secretory granules, and that hypersecretion of these granules in $\mathrm{CF}$ is responsible for the raised calcium concentrations.

The patients studied were attending the Cystic Fibrosis Clinic at the Royal Alexandra Hospital for Children, Sydney, or were contacted through the co-operation of the Cystic Fibrosis Association of New South Wales. This study was supported in part by the Cystic Fibrosis Association of New South Wales.

\section{REFERENCES}

Blomfield, J. (1972). Zymogen granules in the pathogenesis of cystic fibrosis. In Cystic Fibrosis Club Abstracts, 13th Annual Meeting, Kansas City, p. 21.

Chen, P. S., Toribara, T. Y., and Warner, H. (1956). Microdetermination of phosphorus. Analytical Chemistry, 28, 1756.

Chernick, W. S., Barbero, G. J., and Parkins, F. M. (1961). Studies on submaxillary saliva in cystic fibrosis. Fournal of Pediatrics, $\mathbf{5 9}, 890$.

Chernick, W. S., Eichel, H. J., and Barbero, G. J. (1964). Submaxillary salivary enzymes as a measure of glandular activity in cystic fibrosis. Fournal of Pediatrics, 65, 694

Dawes, C. (1969). The effects of flow rate and duration of stimulation on the concentrations of protein and the main electrolytes in human parotid saliva. Archives of Oral Biology, 14, 277.

Dreisbach, R. H. (1964). Effect of isoproterenol on calcium metabolism in rat salivary gland. Proceedings of the Society of Experimental Biology and Medicine, 116, 953.

Gow, B. S. (1965a). Analysis of metals in saliva by atomic absorption spectroscopy. I. Calcium. Fournal of Dental Research, 44, 885 .

Gow, B. S. (1965b). Analysis of metals in saliva by atomic absorption spectroscopy. II. Magnesium. Fournal of Dental Research, 44, 890 .

Gugler, E., Pallavicini, C. J., Swerdlow, H., and di Sant'Agnese, P. A. (1967). The role of calcium in submaxillary saliva of patients with cystic fibrosis. Fournal of Pediatrics, 71, 585.
Horton, C. R., Cole, W. Q., and Bader, H. (1970). Depressed $\left(\mathrm{Ca}^{++}\right)$-transport ATPase in cystic fibrosis erythrocytes. Biochemical and Biophysical Research Communications, 40, 505.

Mandel, I. D., Eriv, A., Kutscher, A., Denning, C., Thompson, R. H., Kessler, W., and Zegarelli, E. (1969). Calcium and phosphorus levels in submaxillary saliva. Changes in cystic fibrosis and in asthma. Clinical Pediatrics, 8, 161 .

Mandel, I. D., Kutscher, A., Denning, C. R., Thompson, R. H. and Zegarelli, E. V. (1967). Salivary studies in cystic fibrosis. Archives of Disease in Childhood, 113, 431.

Seifert, G. (1967). Experimental sialadenosis by isoproterenol and other agents: histochemistry and electron microscopy. In Secretory Mechanisms of Salivary Glands, p. 191. Ed. by L. H. Schneyer and C. A. Schneyer. Academic Press, New York and London.

Selinger, Z., Naim, E., and Lasser, M. (1970). ATP-dependent calcium uptake by microsomal preparations from rat parotid and submaxillary glands. Biochimica et Biophysica Acta, 203, 326.

Taugner, R., and Dreisbach, R. H. (1972). In vitro cellular dynamics by radioautography: calcium-45 in rat salivary glands. Fournal of Pharmacology and Experimental Therapeutics, 180, 657.

Wallach, D., and Schramm, M. (1971). Calcium and the exportable protein in rat parotid gland. Parallel subcellular distribution and concomitant secretion. European fournal of Biochemistry, 21, 433.

Warton, K. L., and Blomfield, J. (1971). Hydroxyapatite in the pathogenesis of cystic fibrosis. British Medical fournal, 3, 570

Wiesmann, U. N., Boat, T. F, and di Sant'Agnese, P. A. (1970). Sodium concentration in unstimulated parotid saliva and on oral mucosa in normal subjects and in patients with cystic fibrosis. Fournal of Pediatrics, 76, 444.

Wiesmann, U., Pallavicini, J. C., Handwerger, S., Swerdlow, H. and di Sant'Agnese, P. A. (1968). Effect of flow rate on electrolytes, carbohydrates and proteins in submaxillary saliva of normal subjects and patients with cystic fibrosis. In Cystic Fibrosis Club Abstracts, Ninth Annual Meeting, Atlantic City, p. 12.

Zall, D. M., Fisher, D., and Garner, M. Q. (1956). Photometric determination of chlorides in water. Analytical Chemistry, 28, 1665.

Zipkin, I., Hawkins, G. R., Damergis, J. A., Gugler, E., Swerdlow, H., and di Sant'Agnese, P. A. (1970). Selected constituents in the parotid and submaxillary saliva of individuals with cystic fibrosis. In Cystic Fibrosis Club Abstracts, Eleventh Annual Meeting, Atlantic City, p. 57.

Correspondence to Miss J. Blomfield, Children's Medical Research Foundation, P.O. Box 61, Camperdown, N.S.W. 2050, Australia. 